\title{
METACOGNITIVE ASPECTS IN INDONESIAN LEARNING IN SENIOR HIGH SCHOOLS IN JEMBER
}

\author{
Alivia Nadatul Aisyi, Sarwiji Suwandi, and Andayani \\ Universitas Sebelas Maret Surakarta, Indonesia \\ Jalan Ir. Sutami No. 36, Kentingan, Jebres, Surakarta, Indonesia \\ Corresponding Author: aliviaaisyi@ student.uns.ac.id
}

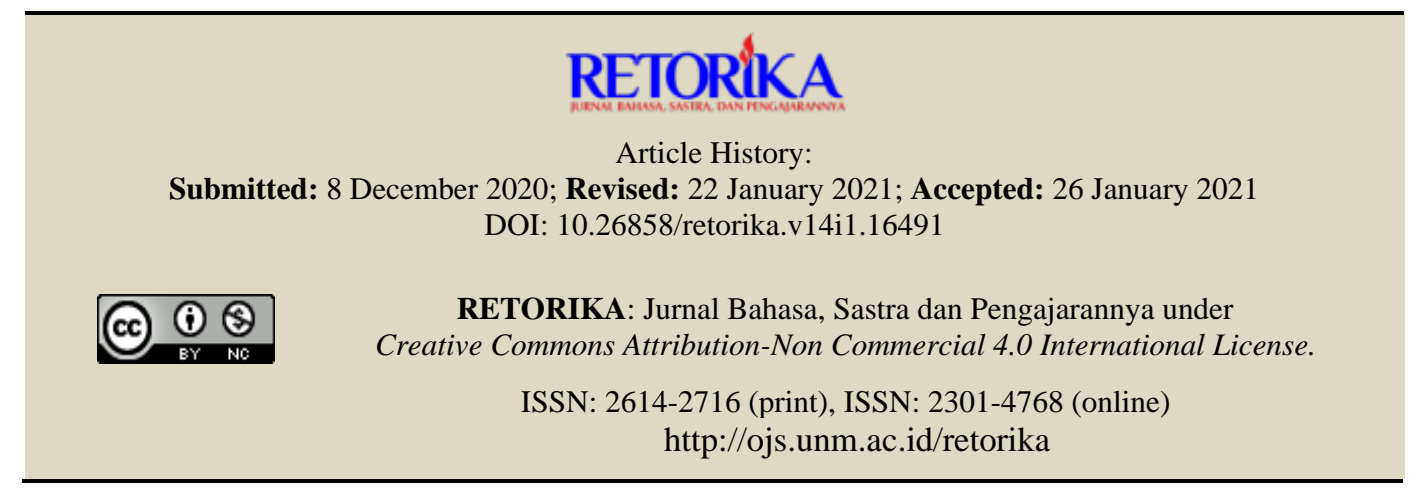

\begin{abstract}
Metacognition is important in learning since it is a higher order thinking process. Metacognition emphasizes on the students' autonomy to determine the learning process which is right for them. This research was conducted on tenth grade class students in Jember. Research on three students was collected through interviews and observations. The research result was obtained in three parts, procedural, declarative, and conditional knowledge in each variable. The variables consist of self, task, and strategy. The results showed that the three metacognitive knowledge were closely related to the student learning process. The highest level in the learning process is procedural knowledge, then declarative and conditional knowledge.
\end{abstract}

Keywords: Indonesian language, language learning, metacognition

Metacognition is very important in learning activities. Flavell $(1979 ; 1981)$ and Flavell, et al (1993) explain for the first time that metacognitive knowledge is a thought process of thinking. This explanation is confirmed by other experts. Krathwohl and Anderson (2009); Brynes (2001); Dunlosky (1998) and Schunk (2012) explain that metacognition consists of knowledge, experience, strategy, and goal. Metacognitive knowledge includes the components of the activities, the subjects, and the strategies used, while metacognitive experience includes feelings of understanding and encouragement for strategy implementation. These strategies use to achieve goals. Besides, the knowledge aspect of metacognition has three elements, namely declarative knowledge, procedural knowledge, and conditional knowledge.

Brynes (2001) adds that declarative knowledge is knowledge about facts or knowing that/what, which means knowledge of 'what', while procedural knowledge is related to knowing how the steps a person takes to achieve a goal. Next knowledge is conditional knowledge, means knowing why, which relates to a form of representation that reflects a person's understanding of his declarative and procedural knowledge. Besides, the metacognition aspect has important 
influencing variables, namely self, task, and strategy variables.

Metacognitive skills, both knowledge and experience are needed. Knowledge relates to students can determine their needs and strategies that will be used to achieve learning objectives. Metacognitive experiences relate to when and how these students must apply these abilities and strategies. Both aspects of both knowledge and experience can describe procedural, conditional, and strategic applications of declarative knowledge to their learning needs. Zhao (2015) explains that metacognition is an abstract concept that may require different preferences regarding the definitions used by various researchers. However, on the whole, metacognition is concerned with "thinking about thinking". In each learning process students examine the strategies, skills, and procedures used on their own. These makes students know autonomously the learning experience being carried out.

Broadly speaking, it can be understood that metacognition is a process of forming student's critical thinking. All processes must be accounted for by the students themselves. Baker and Brown (1984) state that the student has to know 'when and how' to use these strategies and abilities in completing his tasks well. Also, students must be able to be autonomous and discipline towards themselves. The effort is expected to make students achieve the required learning objectives so that they can evaluate themselves related to their learning outcomes. Christoph (2006) explains that this principle of self-regulation requires a structured learning environment to organize learning. Students can actively monitor and control their learning behavior. The use of metacognitive skills is directly related to knowledge transfer. Metacognition makes it possible to monitor a person's learning progress while solving certain problems in a particular learning environment, for example, in certain learning there is a type of learning regulation that is highly recommended.

Indonesian language learning activities have four skills. Mansyur (2016) states the students must master listening, speaking, reading, and writing skills. These four skills need to involve understanding metacognition and monitoring of goals and strategies. Students are expected to be able to set goals, evaluate learning activities, and list what needs to be done to master these skills. Gurbin (2015) adds that the development of metacognitive skills plays a role in helping students to be useful throughout their lives because these skills are necessary for effective learning.

The current curriculum 2013 pays more attention to metacognition. In the Core Competencies knowledge in the 2013 curriculum mentions four things, namely, factual, procedural, conceptual, and metacognitive. Besides knowledge, skills also require attention to metacognition abilities. Students will understand their learning objectives, the strategies to use, and the benefits to obtain so that they can evaluate their abilities. Bransford, et al (2000) argues that metacognition should be integrated into the curriculum in various fields of study because metacognition is a form of internal dialogue between students and those they learnt. Aisyi, et al (2018) supports that learning tailored to their needs can make it easier for students to achieve learning goals. Aisyi adds that the results of her research on contextual textbooks confirm that meaning in the learning process is very significant. Learning that involves fully active students makes learning activities more memorable for students. In Indonesian language learning, this is needed to achieve language learning goals that are relevant to needs. The objective of the knowledge and skills can be achieved by fully involving the role of students' metacognition. In addition, Suwandi, et al (2016) stated that good learning uses good teaching materials, that is teaching materials that can foster genuine responses, be able to provide information, inspire enthusiasm, challenge, increase experience, boost curiosity, and raise the opinion.

Based on this, the role of metacognition is increasingly needed in Indonesian language learning. So that, learning objectives can be achieved properly on the student's needs. Research related to metacognition aspects has been carried out by many previous researchers, especially in Mathematics. It was done by Pilten and Yener (2010), it was found that in mathematics learning in the fifth grade of elementary school students, the role of metacognition was very influential on the students' outcomes. In the results, the student's awareness factor in learning showed learning outcomes in line with students' plans. The students who pay attention to the learning steps well, get good learning results. Based on this research, researchers are interested in conducting research 
on Indonesian language subjects. There is not found research that relates to metacognitive aspects on Indonesian language subject especially, in the tenth-grade senior high school students.

This research focused on the metacognical aspects in the tenth-grade senior high school students in Indonesian. Three elements of metacognitive aspects are declarative knowledge, procedural knowledge, and conditional knowledge by taking into account the impact of self, task, and strategy variables. This research was conducted on learning at Senior High Schools in Jember.

\section{METHOD}

The research design was descriptive qualitative research. The research was conducted in two months, August and September 2020. The data collection techniques in this study were interview, observation, and document study. Indepth interviews were conducted with selected students. Observations were done during the Indonesian language learning process. The researcher acted as a passive researcher who thoroughly observed learning activities. Document analysis was carried out on the results of student tasks who became informants to research related to metacognitive aspects.

Data validation was carried out by data triangulation, theory, method, and researchers. The data was collected by using purposive sampling technique or data collection with the objectives and criteria that have been determined as follows. (1) Students, whether male or female, who were skilled in Indonesian subjects, were shown by high student achievement. (2) Students, both male and female, who did not do well in Indonesian subjects, might cause by low interest. (3) Students, both male and female who were neutral or have standard skills in Indonesian, namely the acquisition of Indonesian scores that was neither too bad nor too good. Based on these objectives, three students were determined who had the criteria based on the teacher's suggestions.

Under the qualitative nature of this research with a case study strategy, the researchers conducted an analysis of existing data using the interactive analysis technique model by
Miles and Huberman (2007: 33). The techniques were (1) the data collection stage, (2) the data reduction stage, (3) the data presentation stage, and (4) the

conclusion or verification stage. Interpretation of data used a scale indicator of 4 , namely (1) less, (2) enough, (3) good, and (4) very good. The more complete explanation is as follows.

\begin{tabular}{ccl}
\hline No. & Criteria & \multicolumn{1}{c}{ Indicator } \\
\hline 1. & Less & $\begin{array}{l}\text { The student has less metacognition } \\
\text { knowledge of self, task, and strategy } \\
\text { variables }\end{array}$ \\
\hline 2. & Enough & $\begin{array}{l}\text { The student has enough } \\
\text { metacognition knowledge of self, } \\
\text { task, and strategy variables }\end{array}$ \\
\hline 3. & Good & $\begin{array}{l}\text { The student has good metacognition } \\
\text { knowledge of self, task, and strategy } \\
\text { variables }\end{array}$ \\
\hline 4. & Very & $\begin{array}{l}\text { The student has very good } \\
\text { metacognition knowledge of self, } \\
\text { task, and strategy variables }\end{array}$ \\
\hline
\end{tabular}

\section{FINDINGS AND DISCUSSION}

\section{Findings}

\section{Procedural Knowledge}

Procedural knowledge is the students' knowledge regarding the steps or learning procedures carried out to understand the material being studied (Schraw and Moshman, 1995). The students' capability to determine procedures or steps to understand the material and complete learning tasks is a major factor in achieving learning objectives. Besides that, there are factors from other variables that are related and very influential, namely the self variable. Students' confidence in their abilities is a major factor for the achievement other variables, namely tasks and strategies. In this study, 3 students were selected by the researcher's criteria and the teacher's recommendation. The students who are randomly selected get various data. Following the results of the interview related to students' procedural knowledge and the variables that influence it (table 1). Giving a score to make it easier for the researcher to classify students' knowledge with scores of 1-4 with the following criteria: (1) less, (2) enough, (3) well, and (4) very good. 
Table 1. The Level of Students' Procedural Knowledge and the Influential Variables

\begin{tabular}{ccccccc}
\hline Students & Procedural knowledge & \multicolumn{3}{c}{ Self Variable } & & \\
\hline & $\begin{array}{c}\text { Students' self- } \\
\text { efficacy (self- } \\
\text { confidence in } \\
\text { completing } \\
\text { tasks) }\end{array}$ & $\begin{array}{c}\text { Students' } \\
\text { beliefs in } \\
\text { goals }\end{array}$ & $\begin{array}{c}\text { Students' beliefs } \\
\text { in values and } \\
\text { interests }\end{array}$ & $\begin{array}{c}\text { Task } \\
\text { Variable }\end{array}$ & Variable \\
& 4 & 3 & 2 & 3 & 3 & 4 \\
\hline 1. & 3 & 2 & 3 & 3 & 2 & 3 \\
\hline 3. & 2 & 2 & 2 & 2 & 3 & 3 \\
\hline
\end{tabular}

Procedural knowledge is the students' knowledge regarding the steps or learning procedures carried out to understand the material being studied. Student 1 had procedural strategies knowledge with excellent grades because student 1 constantly repeated the lessons that he had learned from the teacher at school. However, his efforts had not been able to build high selfconfidence, so that the learning scores obtained in Indonesian subjects were not satisfactory.

Student 2 had good procedural strategies knowledge, but in completing the task, this student still had problems that he could not complete it as a whole. Student 2 was fond of completing practical tasks. Self-variable of student 2 had less confidence to complete the task, but he was quite confident in believing in goals and grades.

Student 3 had a poor value on procedural knowledge because the learning process was determined by the teacher who taught. Student 3 had a passion for learning and also depended on the teacher who taught especially Indonesian subjects. Self-confidence, beliefs related to learning objectives, and interest in Indonesian subject could be categorized as low. Student 3 was fond of learning science subject, so this affected his enthusiasm for learning Indonesian subject. However, the student was quite responsible for the variable schoolwork. Efforts to complete tasks were still carried out with an equally good strategy, namely discussing with peers to increase understanding in learning Indonesian subject.

\section{Declarative Knowledge}

Declarative knowledge is knowledge related to factual information recognized by the students. In case, it relates to students' understanding of the Indonesian language subject that has been learned. The results of the research showed that students' declarative knowledge was strongly influenced by procedural knowledge. Following the results of the scores are based on the interviews that have been conducted with the informants (table 2).

Table 2. The Level of Students' Declarative Knowledge and the Influential Variables

\begin{tabular}{|c|c|c|c|c|c|c|}
\hline \multirow{2}{*}{$\begin{array}{l}\text { Stu } \\
\text { dent }\end{array}$} & \multirow{2}{*}{$\begin{array}{l}\text { Declar } \\
\text { ative } \\
\text { Knowl } \\
\text { edge }\end{array}$} & \multicolumn{3}{|c|}{ Self Variable } & \multirow{2}{*}{$\begin{array}{l}\text { Task } \\
\text { Vari } \\
\text { able }\end{array}$} & \multirow{2}{*}{$\begin{array}{l}\text { Strat } \\
\text { egy } \\
\text { Vari } \\
\text { able }\end{array}$} \\
\hline & & $\begin{array}{l}\text { Stude- } \\
\text { nts' } \\
\text { self- } \\
\text { effica } \\
\text { cy } \\
\text { (self- } \\
\text { confid } \\
\text { ence } \\
\text { in } \\
\text { compl } \\
\text { eting } \\
\text { tasks) }\end{array}$ & $\begin{array}{l}\text { Stud } \\
\text { ents' } \\
\text { belie } \\
\text { fs in } \\
\text { goals }\end{array}$ & $\begin{array}{l}\text { Stud } \\
\text { ents' } \\
\text { belie } \\
\text { fs in } \\
\text { value } \\
\text { s and } \\
\text { inter } \\
\text { ests }\end{array}$ & & \\
\hline 1. & 3 & 2 & 3 & 3 & 3 & 3 \\
\hline 2. & 3 & 2 & 3 & 3 & 3 & 3 \\
\hline 3. & 2 & 2 & 3 & 2 & 3 & 2 \\
\hline
\end{tabular}

Student 1's ability in procedural knowledge still had not influenced declarative knowledge with satisfying results. This was influenced by un-optimal student 1's selfconfidence. Student 1 had done the lesson planning well, but he often felt less competent and master in completing the tasks given by the teacher. This factor made the student low declarative knowledge.

The level of declarative knowledge related to factual knowledge or understanding of the 
material also occurred in student 2. Student 2 had not had maximum results yet because the procedural knowledge had not been done correctly. In addition, student 2's enthusiasm for learning was influenced by the material being learned. If the material being studied was considered not suitable for him, his enthusiasm would decrease.

Student 3 had very low declarative knowledge because his procedural knowledge was influenced by teacher factors. There was no selfconfidence during learning Indonesian subject. Less interest in learning had influenced the results. This required the student's enthusiasm to improve his abilities.

\section{Conditional Knowledge}

Conditional knowledge is knowledge related to when a procedure, strategy, or ability is used and when it is not used. Besides that, students have the knowledge to determine which procedures are good and not for their condition and situation. Following the result of the scores are based on the interviews that had been conducted with the informants (table 3 ).

Table 3. The Level of Students' Conditional Knowledge and the Influential Variables

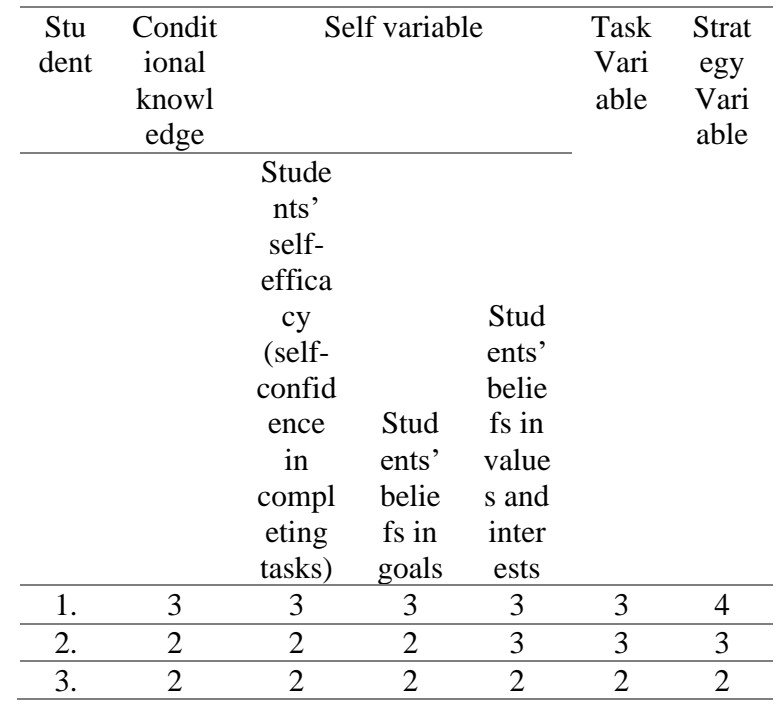

In the research conducted on 3 students, it was found that student 1 had good conditional knowledge and was balanced with procedural and declarative knowledge. Student 1 was more capable to determine the right strategy to use in certain Indonesian language material. For example, during the speech text material, student
1 looked for additional material for speech material from a bulletin or wall magazine to expand his know-ledge.

Student 2 had fairly good conditional knowledge. It was caused that student 2 still followed his perception in exploring the material. If an Indonesian language material was considered unpleasant for student 2, then student 2 selected not to increase his learning strategy.

Likewise, student 3 had very low ability to determine learning strategies that were good for him. It was caused student 3 depend on the teacher who taught. His motivation was low in Indonesian language subject. Student 3 explained that his spirit in learning Indonesian was influenced by the teacher's strategy in teaching. This affected on students' learning goals. The value and fulfillment of Indonesian language tasks were not fulfilled properly. Low conditional know-ledge affects procedural knowledge and declarative knowledge.

\section{Discussion}

Based on the results above, it showed that the metacognitive aspect is a factor that greatly influences the level of students' knowledge. Likewise, it also states in Devika and Singh's (2019) research on metacognition which says that metacognitive awareness is an advanced understanding in the implementation of skills. It helps students not only gain knowledge about their own cognitive processes but also manages learning activities. Three aspects of metacognitive knowledge play a major role in the learning process.

The first factor is procedural knowledge. Proper procedural knowledge in the learning process determines students' abilities. However, there are still other variables, namely self, task, and strategy variables that must go hand in hand. The student with high self-confidence in his abilities is more capable to determine the learning strategies being used, while the student with low self-confidence influences on determining learning procedures that are suitable for him. The results of the study are in line with Pilten and Yener (2010) which states that procedural knowledge is the highest level in the metacognitive aspect.

The next level of knowledge is declarative knowledge. Declarative knowledge relates to 
facts influences the level of student understanding of the lessons which have been learned. The student with high understanding of the material is influenced by careful preparation. The student can determine learning procedures that are appropriate and suitable for them so that the student's learning objectives can be achieved.

In contrast to conditional knowledge, as explained by Brynes (2001), which states that conditional knowledge is applicable to procedural and declarative knowledge so that the role of conditional knowledge becomes complementary. Apart from this, the metacognitive knowledge must still be considered by the students in the learning process by having full awareness of the importance of metacognitive roles. This study has similarities with Pilten and Yener's research in the focus of the research, but the difference is that the research was conducted on the fifth-grade elementary school students, while this research was conducted on the tenth-grade senior high school students.

There is also research conducted by Mohamed (2012) on the relationship between metacognition and self-regulation. It is found that there is a close relationship between the two. The difference is that the study does not discuss elements of self-regulation. Mohamed conducted research on early childhood, while the researcher conducted on the tenth-grade senior high school students. The differences in metacognition outcomes are clear. The tenth grade students are able to determine the steps of learning according to their awareness and consider their interests, while early age students still have to be assisted by teachers who direct their metacognition.

In addition to the two previous studies that have been mentioned, there is research from $\mathrm{Xu}$, et al (2012). Research is carried out related to metacognitive knowledge with three elements, namely procedural knowledge, declarative knowledge, and conditional knowledge. In contrast that $\mathrm{Xu}$, et al (2012) only examined the task and strategy variables, while this study examined the self, task, and strategy variables. The researcher chooses not to let go of the self variable because the students are the most important aspect in metacognitive research. Metacognition relates to students' high-level thinking with full awareness so that they cannot eliminate the self-variable in their research activities.

Based on the three previous studies that have been carried out, this study has similarities that make references and has differences as a novelty from previous studies. The implications of this research for language teaching are equally beneficial for the teachers and the students. The students' awareness in Indonesian language learning activities, both related to awareness of their interests and talents, can improve student learning outcomes. On the other hand, when students do not plan consciously Indonesian language learning activities that are being carried out will affect the acquisition of student learning outcomes. Students' awareness of the metacognitive aspects makes it easier for teachers to evaluate students' learning outcomes. The teacher can also make small observations before learning takes place to find out what steps students will learn to take.

\section{CONCLUSION}

Based on the research conducted, it can be concluded as follows. (1) Based on the obtained points in the procedural knowledge which showed high numbers. Students who have procedural knowledge in the learning process can carry out the learning process with the flow or plan that has been determined by them. This shows that procedural knowledge is the highest level of the metacognitive aspect. In addition, students' procedural knowledge shows the influence of self-confidence on task fulfillment and determining learning strategies. Students who understand their strengths and weaknesses are more likely to complete their tasks easily. (2) Acquiring points on declarative knowledge reinforces data on procedural knowledge. Declarative knowledge is related to the knowledge that students acquire. Students who have high confidence values and the ability to determine learning steps are able to achieve learning outcomes as desired. Therefore, declarative knowledge is knowledge at the second level of metacognitive aspects. (3) The third element of metacognitive knowledge related to conditional knowledge which affects the choice of learning strategies or suitable procedures is the last level of knowledge because students who are able to determine which procedures are right for completing assignments must be accompanied and follow the teacher's directions.

This research still has weaknesses and limitations, which the research was only 
conducted on the three students selected according to the teacher's direction because they considered the limited time during pandemic Covid-19. In addition, this research interview was conducted virtually using the WhatsApp application because of limitations to face-to-face at online school.

\section{REFERENCES}

Aisyi, A. N., Muti'ah, A., \& Pornomo, B. E. (2018). Bahan Ajar Menulis Teks Prosedur Berbasis Kitab Safinatun Najah di Lingkungan Pesantren. Retorika: Jurnal Bahasa, Sastra, dan Pengajarannya, 11 (2), 108--18.

Baker, L., \& Brown, A. L. (1984). Metacognitive skills and reading. Handbook of reading research, 1 (353). Newyork: Longman.

Bransford, John, Brown, \& Cocking. (2000). How People Learn: Brain, Main, Experience, and School. National Research Council (US): Commite on Development in the Science of Learning.

Brynes, J. P. (2001). Cognitive Development and Learning in Instructional Contexts ( $2^{\text {nd }} \mathrm{Ed}$.). Needham Heights, MA: Allyn and Bacon.

Christoph, L. H. (2006). The Role of Metacognitive Skills in Learning to Solve Problems. SIKS.

Devika, \& Singh, R. (2019). Influence of Metacognitive Awareness on Engineering Students' Performance: a Study of Listening Skills. Procedia Manufacturing. 31: 136--141.

Dunlosky, J. (1998). Epilogue: Linking Metacognitive Theory to Education. In D. Hacker, J. Dunlosky. \& A. Graesser (Eds), Metacognition in Educational Theory and Practice (pp. 367-381) Mahwah, NK: Lawrence Erlbaum.

Flavell, J. H. (1979). Metacognition and Cognitive Monitoring: A New Area of Cognitive Development Inquiry. American Psychologist, 34 (10): 906--911.

Flavell, J. H., Miller, P. H., \& Miller, S.A. (1993). Cognitive Development. New Jersey: Englewood Cliffs.

Flavell, J.H. (1981). Cognitive Monitoring. In W. Dickson (Ed.), Children's oral Communication Skills. New York: Academic Press.

Gurbin, T. (2015). Metacognition and Technology Adoption: Exploring Influences. ProcediaSocial and Behavioral Sciences, 191, 1576-1582.
The recommendations are expected to be useful for future researchers who are interested in conducting the students' metacognitive aspects that can conduct research based on metacognitive experiences by expanding respondents, so the results related to metacognitive aspects can be more various and broad.

Krathwohl, D. R., \& Anderson, L. W. (2009). A Taxonomy for Learning, Teaching, and Assessing: A Revision of Bloom's Taxonomy of Educational Objectives. Longman.

Mansyur, U. (2016). Inovasi Pembelajaran Bahasa Indonesia melalui Pendekatan Proses. RETORIKA: Jurnal Bahasa, Sastra, dan Pengajarannya, 9 (2).

Miles, M. B. \& Huberman, M. (2007). Qualitative Data Analysis A Methods Sourcebook. Amerika: Sage Publications.

Mohamed, A.H.H. (2012). The Relationship between Metacognition and Self-regulation in Young Children. Procedia-Social and Behavioral Sciences, 69, 477--486.

Pilten, P., \& Yener, D. (2010). Evaluation of metacognitive knowledge of 5th grade primary school students related to non-routine mathematical problems. Procedia-Social and Behavioral Sciences, 2 (2), 1332--1337.

Schraw, G. \& D. Moshman. (1995). Metacognitive Theories. Educational Psychology Review, 7: 351-- 371 .

Schunk, D. H. (2012). Learning Theories: An Educational Perspective $6^{\text {th }}$ ed. Terjemahan Hamdiah \& Rahmat Fajar). Yogyakarta: Pustaka Pelajar.

Suwandi, S., \& Yunus, A. (2016). Kecerdasan Ekologis Dalam Buku Sekolah Elektronik Mata Pelajaran Bahasa Indonesia SMP. LITERA, 15 (1).

Zhao, Zhanqiang. (2015). Mainland Chinese Students' Metacognition, Including their Conception of Learning: A Phenomenographic Study in Hebei and Shandong Provinces. University of Alberta: Department of Secondary Education.

Xu, W., Carifio, J., \& Dagostino, L. (2012). Constructing a Metacognitive Knowledge Framework for Post-Secondary EFL Reading Teachers' Summarizing Strategies Instruction with Expository Text: A Case Study, Phase I. Creative Education, 3 (06), 829 